\title{
PSYCHE
}

VOL. XXII JUNE, 1915 No. 3

\section{THE ORIGIN OF ANTHOPHILY AMONG THE COLEOPTERA.}

\author{
By John H. Loveld, \\ Waldoboro, Maine.
}

As pollinators of flowers the Coleoptera are less important than either the Hymenoptera, Diptera, or Lepidoptera. Of the total number of described species the majority are largely inhibited from visiting flowers by their forms or habits; many are predaceous both in the larval and adult stages, or are scavengers; others are nocturnal, or aquatic, or occur chiefly on the ground lurking beneath stones and boards, or living in the nests of other orders of insects; while round or elliptical forms with short legs and very large species are ill-adapted to anthophily. Knuth has enumerated 434 beetles in Europe and the Arctic regions as anthophilous; ${ }^{1}$ and in the world outside of Europe 223 species, of which 185 belong to North America. ${ }^{2}$ Since the appearance of Knuth's work a few partial lists of the species collected in various localities in the United States have been published. In Wisconsin Dr. Graenicher has recorded 35 beetles as visitors to the Compositæ; ${ }^{3}$ in Virginia Dr. Banks has listed 58 species taken on the flowers of Ceanothus, ${ }^{4}$ and in California Hopping collected 56 species on the same inflorescence; 5 wile many additional flower-records are given in Blatchley's "Coleoptera in Indiana."

The order of the Coleoptera is of special interest, says Hermann Muiller, since it shows so clearly the beginnings of anthophily, and

1 Knuth, Paul, "Handbuch der Blutenbiologie," Vol. 2, p. 560.

${ }^{2}$ Loc. cit., Vol. 3 , p. 366.

${ }^{3}$ Graenicher, S., "Wisconsin Flowers and Their Pollination," Bull. Wisconsin Soc. Nat. Hist., Vol. 7, pp. 19-77.

${ }^{4}$ Banks, N., "At the Ceanothus in Virginia," Ent. News, Vol. 23, pp. 102-110.

${ }^{5}$ Hopping, Ralph, "Some Notes of Coleoptera Found on Species of Ceanothus," Ent. News, Vol. 10, pp. 162-165. 
the first corresponding modifications. In the most diverse families, accustomed to widely varying nourishment, single species have become habituated, first partially, then exclusively to a floral diet, and subsequently structural changes have been developed to insure greater success in the search after food. The length of time which has elapsed since the first tendency in a family toward anthophily is indicated by the number of species which resort to flowers. Where a whole family is dependent on a floral diet the epoch was more remote, but where there are only a few isolated species the habit has been acquired more recently. ${ }^{1}$

During the past ten years Mr. C. A. Frost and the writer have devoted much attention to the anthophilous Coleoptera of New England. Mr. Frost has worked chiefly at Framingham, and the neighboring towns of Sherborn and Hopkinton, Mass.; while the writer has collected wholly at Waldoboro, Me. As a result a larger number of species has been taken than would have been obtained by a single observer working in one locality. In the appended list there are enumerated for New England 232 anthophilous species belonging to 127 genera and 29 families, or 47 species more than Knuth records for all North America. Of this number 185 species were collected in Massachusetts, and 102 in Maine, 57 species being common to both states, while two species are credited to New Hampshire only. The number of genera in Massachusetts is 100, and in Maine 73, with 46 genera common to both states. It is clear that all the families of marked significance in flower pollination in this section have been recorded, for 20 families, including 222 species, are common to both states, while each of the nine families listed from one state is represented only by a single species, or in one instance by two. Although further observations in other localities would add many species and genera to the list, there can be no doubt that the 46 genera common to both states cover most of the forms beneficial to flowers in northern New England. Where a large number of species in a genus, as in Lebia, Typocerus, Leptura, Strangalia, Telephorus, Hoplia, Trichius, Mordella, Mordellistena, and many others are known to resort to flowers, it is generally safe to conclude that the entire genus is anthophilous; but when a species has been taken only once

\footnotetext{
${ }^{1}$ Müller, Hermann, “Fertilization of Flowers,” p. 36.
} 
it may be excessively rare, e. $g$., a single specimen of Megapenthes rogersii was found on the flowers of Viburnum alnifolium in Maine and while this beetle has been reported from Canada and the southern shore of Lake Superior this is the only known record of its occurrence in New England. Where genera are represented in the list by a single species, if this form is very common it will be found recorded from more than one locality, as Chauliognathus pennsylvanicus and Epicauta pennsylvanica. The severe climatic and edaphic conditions in southern Maine, where the hills are covered with coarse glacial debris and the valleys with a subsoil of heavy clay, and sudden extremes in temperature and open winters prevail, are unfavorable to a rich insect fauna; and account for the larger number of anthophilous species collected in Massachusetts. The observations of Dr. Banks in Virginia would indicate that as we proceed southward the number of anthophilous Coleoptera would progressively increase.

Loew has divided the anthophilous Coleoptera, according to their adaptations as flower visitors, into three groups termed by him hemipterous, allotropous and dystropous. The hemipterous beetles are partially adapted to visiting flowers, as the genera Chauliognathus, Gnathium, and Nemognatha. The allotropous species, which include the greater number of anthophilous Coleoptera, are of little value in pollination, and structural modifications for procuring nectar are indistinct or absent. This group is still further subdivided according to the food habits of the respective families both in the larval and adult stages. The dystropous beetles are detrimental or destructive to flowers, as the Chrysomelidæ, Rhyncophora, and the Melolonthinæ (a subfamily of the Scarabæidæ). While this arrangement is helpful in estimating the value of the Coleoptera in pollination we shall not follow it in the present paper; but shall take up the different anthophilous families in the order of their historical development. The sarcophagous Coleoptera, or where saprophagous living chiefly on decaying or dried animal substances, are certainly more primitive than the phytophagous families which feed on wood, sap, leaves and other vegetable matter; while in this second group the xylophagous families are apparently older than those living exclusively on foliage or a floral diet. In reviewing the rise of the anthophilous habit we shall consider, first, isolated anthophilous genera in 
sarcophagous families; second, genera in phytophagous families, of which the species occasionally or frequently resort to flowers, and finally families which are largely anthophilous.

\section{Anthophily of the Sarcophagous Families.}

Carnivorous families, especially where they live upon the ground or are aquatic, are not likely to visit flowers. None of the terrestrial Cicindellidæ (tiger beetles), or aquatic Dytiscidæ (water tigers), which are highly predaceous both in the larval and adult stages, have ever been observed feeding on pollen or nectar. Among the predaceous Carabidæ, or ground beetles, Lebia is the only genus which has become widely anthophilous. ${ }^{1}$ Knuth, who saw Carabus cancellatus on the Island of Föhr devouring the flowers of Thymus Serpyllum, expresses the opinion that the most markedly predaceous beetles may occasionally visit flowers, but such visits are clearly accidental. ${ }^{2}$ Frost in Massachusetts also saw Harpalus caliginosus eating the seeds of Ambrosia artemisifolia. Although living chiefly beneath stones, logs and rubbish, a part of the Carabidæ occasionally ascend plants in search of insect larvæ; thus Morris relates that he has "once taken Calosoma scrutator, and several times $C$. calidum on the foliage of the white pine, these enterprising ground beetles poaching on the arboreal preserves for caterpillars; many of the diurnal fireflies, which are carnivorous, may be found resorting to foliage for the same purpose." 3 Plantlice and the pollen of grasses and the Compositæ have likewise been found in the stomachs of many species. ${ }^{4}$ Nine species of Lebia, of which $L$. ornata and $L$. viridis are the most common, appear in the New England list; eight species have been collected on Solidago, a half dozen specimens being found at times on a single inflorescence; but a variety of other flowers are also visited as recorded. These small beetles still feed partially on Aphides and insect eggs, and it was undoubtedly the search for food on foliage which led to flower-visiting. The constriction of the head behind the eyes into a neck, and the fringe of hairs on the inner margin of the maxillæ cannot be regarded as special adaptations to anthophily, since the

\footnotetext{
1 According to Blatchley, Callida punctata is often found on flowers. "The Coleoptera in Indiana," p. 152.

2 Knuth, Paul, "Handbuch der Blütenbiologie," Vol. 1, p. 221.

3 Morris, F. J. A., "Beetles Found about Foliage," Can. Ent., Vol. 43, p. 111.

4 Blatchley, W. S., “The Coleoptera in Indiana," p. 37.
} 
former occurs in Galerita which is wholly carnivorous, and the latter in genera which never visit flowers.

The Staphylinidæ, or rove-beetles, characterized by the short elytra, while partially saprophagous, are more generally carnivorous than is commonly supposed. Of the four anthophilous genera listed for New England, Anthobium, which includes very small beetles feeding largely upon pollen, is the most important. A. pothos has been taken by the writer devouring the anthers of Clintonia borealis; and in Indiana $A$. convexum is especially common on the flowers of the red-berried elder (Sambucus racemosa), ${ }^{1}$ which is devoid of nectar (pollen flowers). The rich proteid content of pollen naturally renders it an attractive food to carnivorous beetles. The Carabidæ and Staphylinidæ well illustrate how difficult it is for predaceous families living upon the ground to acquire the anthophilous habit.

The larvæ of the Coccinellidæ are common on foliage where they feed chiefly on Aphides, while the beetles not infrequently resort to flowers, as is shown by the seventeen species listed. The tendency to seek floral food is most strongly manifested in the genera Coccinella and Hippodamia. In consequence of their short legs and round or oblong-oval forms the lady-bugs are exceedingly awkward and inefficient flower visitors, and are of little significance in pollination. They climb smooth stems with great difficulty and I have seen one of these beetles slip backward five or six times before it succeeded in ascending a pedicel of an umbel of Aralia hispida. After examining the contents of the stomachs of 39 species Dr. S. A. Forbes concluded that "the function of the beetles of this family of limiting the multiplication of plant-lice is expressed by the fact that these insects compose a fourth of the food of the entire collection. The pollen of grasses and the Compositæ make 14 per cent. and the spores of lichens 4 per cent. and those of fungi 45 per cent., or nearly half the whole." ${ }_{2}$ While the Coccinellidæ consume a much larger quanity of pollen and spores than of nectar, they may be found occasionally sucking on small open flowers.

Ten species of the Dermestidæ, so destructive to decaying animal substances, skins, dried insects, feathers, woolens and carpets, have been taken in New England on flowers. Like the Coccinellidæ

1 Blatchley, W. S., "The Coleoptera in Indiana," p. 487.

2 "Coleoptera in Indiana," p. 507. 
their visits are chiefly for pollen, and they are not infrequently found on pollen flowers, as Rosa, Anemone, and Thalictrum polygamum. The genera which are anthophilous are usually those which contain very common species, as Anthrenus and Attagenus. Comstock says of the carpet beetle (Anthrenus scrophulario) that in its adult stage it feeds on the pollen of flowers, and sometimes abounds on the blossoms of currant, cherry and other fruits. ${ }^{1}$ The little white larvæ of Byturus unicolor infest the fruit of the raspberry, and the small, pale brown beetles often visit the flowers. Cryptorhopalum is common on the blossoms of Cornus, Viburnum, Spiræa and Solidago; but most of the genera may live indefinitely without making flower visits.

The Nitidulidæ are called sap-feeders since they may be found in great numbers in spring at sap flowing from the trunks of trees; but many species live in fungi, or devour dry animal and vegetable matter, and the larvæ of a few genera, as Ips and Carpophilus, are carnivorous so that the family constitutes a transition group. The mature beetles readily feed on nectar or the juices of fruits, and as they are of small size are able to creep into tubular corollas; but usually they are taken on flowers with visible nectar. Of the five genera which appear in the New England list, Carpophilus, Cercus, and Epuraea are the more important. In Europe Knuth enumerates more than 150 flowers which are visited by Meligethes, this being one of the few genera the larvæ of which live on flower food. ${ }^{2}$ The Nitidulidæ also visit pollen flowers, as Rosa, Sambucus, Anemone and Papaver.

The familiar fireflies, or Lampyridæ, are carnivorous both in the larval and adult stages; the larvæ live chiefly on the ground, but the mature beetles may generally be found on the stems, under the bark, or on the foliage of trees, shrubs, and herbage. As in the Carabidæ many genera are nightflyers, which lessens the probability of their becoming anthophilous; but the species are more common on foliage than the ground beetles and are consequently more frequently taken on flowers. The New England list contains 18 species as against 15 recorded by Knuth for Europe and the Arctic regions. The genera Lucidota, Ellychnia and Podabrus

\footnotetext{
1 Comstock, J. H., “Manual of Insects,” p. 540.

2 Knuth, Paul, "Handbook of Flower Pollination," translated by J. R. Ainsworth Davis, Vol. 1, p. 185.
} 
search for plant-lice and insect larvæ on vegetation, and often visit densely clustered inflorescences with visible nectar, as Cornus, Viburnum, Spiraea salicifolia, Pyrus arbutifolia, Prunus virginiana and Achillea Millefolium. The anthophilous tendency is more strongly marked in Telephorus, which, although still remaining partly predaceous, includes nine species taken on flowers.

Special interest attaches to Chauliognathus, one of the few genera of the Coleoptera, which have become modified in structure as a result of anthophily. The mature beetles live wholly on a floral diet, but the larvæ still retain the carnivorous habit. The species are diurnal, the head is long and prominent instead of being retracted under the thorax as is common in this family, and the maxillæ are extensile with the outer lobes prolonged into an oblong pointed process. The modified maxillæ are able to suck nectar in flowers where it is concealed at a depth of one or two millimeters. C. pennsylvanicus is very common on the Compositæ, especillly on the flowers of Solidago; while C. marginatus, occurs in Indiana, according to Blatchley, by thousands on the flowers of the linden, Jersey tea, and wild hydrangea, and in Virginia, according to Banks, is very abundant on Ceanothus. All of the anthophilous species of the Lampyridæ feed on pollen as well as nectar.

The Cleridæ live chiefly on insect larvæ found on vegetation, and are predaceous in both the larval and adult stages. It is a misnomer to call these handsome beetles flower beetles since only nine species have been observed on flowers, of which four belong to the genus Trichodes; many species are rare and little is known of their habits. Trichodes restricts itself wholly to a floral diet. ${ }^{1}$

The series of carnivorous families may be closed with the Malachiidæ, all the species of which are stated incorrectly by Knuth to live solely on flower food when they are adult. The family is of small extent and is sometimes incorporated with the Lampyridæ to which it is closely allied. The larvæ are carnivorous, and most of the genera in the mature stage may be found on foliage hunting for plant-lice and insect eggs; but Attalus, Collops and Malachius and probably many other genera frequently visit flowers for pollen and nectar. Four genera and five species are listed for New England. Very little is known about the habits of the majority of these small beetles.

1 Müller, "The Fertilization of Flowers," p. 33. 
In reviewing the carnivorous Coleoptera it has been repeatedly shown that anthophily prevails to a much greater extent in those families which seek their prey on vegetation than in those which live wholly on the ground; and among the former there may occur genera which both in the larval and adult stages feed on flower food alone. In only one genus, Chauliognathus, have the mouthparts become specialized for sucking nectar. Comparatively few species are anthophilous and owing to the irregularity and uncertainty of their flight they are of little value in pollination; but on the other hand they are detrimental only to a small extent. They have been taken chiefly on small densely aggregated flowers with visible nectar, or nearly visible nectar, as Cornus, Viburnum, Rhus, Spiræa, Fragaria, Rubus, Cratægus, Pyrus, Prunus, Ceanothus, Daucus, Solidago, and a variety of other umbelliferous and composite flowers. They also often visit pollen flowers, as Rosa, Anemone, Papaver and Sambucus; but in general they feed more freely on pollen than nectar, partly because it is more easily obtained, and partly perhaps because it more nearly resembles in its chemical composition the animal food to which they are accustomed. Since all of the anthophilous genera and probably most of the anthophilous species have evidently acquired this habit independently, it may be inferred that the sarcophagous families had very nearly attained their present stage of development before they began to visit flowers.

\section{Anthophily of the Phytophagous Families.}

Among the families, which live upon vegetable substances both in the larval and adult stages, anthophily assumes much greater importance than among the carnivorous forms. The phytophagous species are naturally brought into proximity with flowers, and it is an easy step to acquire the habit of feeding on pollen and nectar; but in a vast number of tubular and zygomorphic flowers the nectar is so deeply placed that it is beyond the reach of beetles. The larvæ of the Elateridæ or click beetles, infest the roots of grains and grasses; while the adult beetles live under the bark, or on the foliage of trees or herbage, and are, according to Morris, very fond of sunshine. The New England list contains 13 genera and 39 species, a greater number than Knuth enumerates for Europe and the Arctic regions. The convex head is deeply in- 
serted in the thorax and permits the Elateridæ to feed only on exposed nectar; accordingly, the common genera Agriotes, Corymbites, Elater and Melanotus are found chiefly on the inflorescence of Rubus, Viburnum, Prunus and Cornus.

The Buprestidæ, which superficially resemble the Elateridæ, are most abundant in the tropics and are of little significance in pollination either in Europe or North America. The larvæ are wood-borers, and the mature beetles live on vegetation. A single species (Acmaeodera tubulus) has been taken in New England by Frost on the flowers of Geranium, Viburnum and Rubus; the same species, according to Blatchley, is very common in Indiana on Geranium maculatum. Knuth lists only three species of this family for North America.

The leaf-beetles or Chrysomelidæ have attained their highest development in the more recent periods according to Leconte and Horn; ${ }^{1}$ the species are diurnal, of small or medium size, and are classed as dystropous by Loew. In both the larval and adult stages this family is very destructive to foliage, and the ravages of the potato beetle have been little less than a national calamity. Since their round or oval forms, retracted head partially or wholly concealed beneath the thorax and short legs, are ill-adapted to anthophily, the New England list contains only 20 species belonging to 16 genera. It is clearly impossible for this immense family of ravenous feeders to become exclusively anthophilous, for the flower food available would be wholly inadequate to their requirements; but there are, doubtless, a large number of occasional visitors. No genus in America is more common or has been taken on a greater variety of flowers than Diabrotica.

The entire life cycle of many leaf-beetles is passed on a single plant species or genus. Donacia piscatrix is found in the flowers of Nymphoa advena, while the larvæ mine in the stems and leaves. Donacia emarginata, near New York City, is very common on the bright yellow flowers of Caltha palustris half buried among the stamens. The pupal cocoons are attached to the stems just above the roots, and the beetles emerge as the flowers expand and climb the stems to obtain flower food. ${ }^{2}$ All of the species of Donacia are commonly found on aquatic or marsh plants. Crio-

${ }^{1}$ Blatchley, W. S., “The Coleoptera in Indiana," p. 1096.

2 Woodruff, L. B. “Donacia emarginata," Can. Ent., Vol. 45, p. 210. 
cerus asparagi visits the flowers of the cultivated asparagus, and the larvæ devour the vegetative organs; Chalepus dorsalis visits the flowers of the black locust (Robinia) and the larvæ mine the leaves; while both stages of the Colorado potato beetle are familiar on the flowers and foliage of the potato.

Both the New England list and Knuth's list for North America contain only two species of the Bruchidæ. This small family is closely allied to the Chrysomelidæ; but the larvæ live in seeds, chiefly those of leguminous plants, while the beetles occur on foliage and occasionally on flowers.

In accordance with their food habits the Scarabæidæ are popularly divided into two large, well-defined groups, the scavengers and leaf-chafers. The scavengers are largely ground forms feeding chiefly on dung, a few on fungi and a few on animal substances. They seldom visit flowers, but on one occasion I captured the common Aphodius fimetarius on the flowers of Spirce salicifolia. The leaf-chafers, or Melolonthinæ, to which belong the genera Hoplia, Macrodactylus and the nocturnal Lachnosterna, are dystropous forms frequently defoliating shrubs and trees. Hosts of rose-chafers (Macrodactylus subspinosus) often strip rose bushes and other shrubs of both flowers and leaves, or devour the blossoms and ruin the crop of grapes. But Hoplia trifasciata "is almost entirely a pollen feeder like Trichius piger and Euphoria inda," 1 and visits a great variety of flowers. The behavior of $T$. piger on Iris versicolor has been described by Needham: "The species is not ill-adapted by its size for visiting these flowers, and, should it pass from flower to flower, it might be an important agent in pollen distribution; but I have not seen one pass from flower to flower directly and am inclined to think it rarely does so. It is little disposed to flight and is much more at home clambering among the thyrsoid clusters of Rhus and Ceanothus. Furthermore, on reaching an Iris flower it is habitually deceived as to the point of entrance and tries for some time to get in at its center, between the branches of the cleft style." In warm regions the Cetoniæ are important flower visitors, and Delpino formerly regarded them as the chief pollinators of Magnolia. We have taken 11 species of the Scarabæidæ on flowers in New England, and Knuth lists only

${ }^{1}$ Morris, F. J. A., "Beetles Found about Foliage," Can. Ent., Vol. 43, p. 115. 
10 species for North America-a very small number certainly in comparison with the great size of this family.

The snout-beetles, or Rhyncophora, an immense group of beetles highly injurious to vegetation, also includes few anthophilous species. The larvæ feed on roots, mine underbark, but chiefly live in nuts, fruits and seeds, while the adults are found mostly on leaves, only 18 species having been observed on flowers in New England. Two common species are the plum weevil (Conotrachelus nenuphar), which sometimes destroys the plum and cherry crop, and is common on the flowers of Prunus virginiana; and the blue-flag weevil which passes its entire life on the blue flag (Iris versicolor). The economy of the blue-flag weevil (Mononychus vulpeculus) has been very fully described by Prof. Needham; ${ }^{1}$ the larval stage is passed within the seed capsule where the transformation into the imago takes place, and both beetles and seeds are set free by the bursting of the capsule in the fall. This weevil wastes the nectar inordinately. It makes many punctures in the nectariferous tissue from which the nectar continues to flow, attracting swarms of insects of all kinds. Eight species of beetles were observed feeding at the punctures, besides many flies. The flag weevil picks up stray grains of pollen but it is of no importance in pollination. "It has become adapted to living on the blue flag exclusively." The life history of many other snout-beetles is confined to a single plant species, but as pollinators they are of little importance and are classed among the dystropous forms.

To the floroecologist no family of the Coleoptera is of greater interest than the Cerambycidæ, or wood-borers, a group the origin of which dates back to an earlier period than that of the Chrysomelidæ. This is partly because it contains many species, which wholly or partially depend on a floral diet; and partly because of modifications resulting from the anthophilous habit. For New England 39 species are enumerated, while Knuth lists 29 for North America, and 42 for Europe and the Arctic regions. Many genera of the tribe Lepturini, as Pachyta, Gaurotes, Typocerus, Leptura and Strangalia, feed entirely on flower food. Nineteen species of Leptura have been collected on flowers in New England, the largest number ever recorded, and no doubt the entire genus is anthophil-

${ }_{1}$ Needham, James G., "The Fruiting of the Blue Flag (Iris versicolor L.)," Amer. Nat., Vol. 34, p. 370 . 
ous. As in 41 instances the species were observed by the writer sucking nectar on the flowers of Aralia hispida and in only two cases eating pollen, they would appear to manifest a preference for nectar, as do the allied genera Typocerus and Strangalia. Both lobes of the maxillæ are fringed with long bristly hairs, which enables them to lick up nectar easily. But pilosity of the maxillæ, either of one or both lobes, must not be regarded as a character peculiar to the Lepturini; for, according to Leconte and Horn, the entire family of the Cerambycidæ is characterized by having "the maxillæ furnished with bristles." At my request, Frost examined species belonging to 13 tribes, found in North America, and in all cases there were bristly hairs on the apices of the maxillæ. All, therefore, that can be claimed for the Lepturini is that the maxillary hairs are in general longer and less bristle-like than in other tribes; and this statement is sustained by the examination of microscopic preparations of the maxillæ of various species. It was further believed by Muiller that the elongation of the head forwards, a neck-like constriction behind the eyes and consequently the power to direct the head forwards, and the prothorax elongated and narrowed anteriorly were structural characters acquired for feeding on nectar whether superficially or more deeply placed. ${ }^{1}$ These conclusions, although they have long been accepted without question, appear to the writer doubtful. In Müller's time structural modifications, which enabled insects to obtain flower food, were readily assumed to have been developed specially for that purpose, often without careful consideration that they might have been determined at an earlier period by the habits of the insect.

The Lepturini are wood-borers and their narrow cylindrical forms have been determined by their well-known economy. The transformations of the larvæ take place in their burrows in the solid wood, and the imagoes are compelled to gnaw their way to the surface, for which purpose an elongated head which could be directed forwards would be a great advantage. Moreover a constriction of the head behind the eyes occurs in beetles which are unknown on flowers. The form of Leptura vittata is very narrow (a specimen before me is $3 \mathrm{~mm}$. wide and $14 \mathrm{~mm}$. long) and the elongated thorax is correlated with the elongated cylindrical abdomen; in L. chrysocoma the abdomen is broader and the thorax

1 Müller, H., “The Fertilization of Flowers," p. 35. 
is also shorter and more robust; in Strangalia again the elongated thorax is correlated with a long slender abdomen. ${ }^{1}$ While the cylindrical forms of these beetles are an advantage in visiting flowers, the genera of the Lepturini were probably essentially differentiated before they became anthophilous. The influence of insect economy in modifying the structure of the head and thorax is well illustrated by the Rhyncophora, which are, as has been shown, of little significance in pollination. The front of the head is prolonged into a slender beak, and in some species the head behind the eyes is constricted into a neck, and the thorax is elongated and narrowed anteriorly. But in this group it is clear that the morphology of the head and thorax was very early determined in its phylogenetic history by the habit of excavating the little pits in which the eggs are laid.

But in the genera Gnathium and Nemognatha of the Meloidæ there occur undoubted modifications of the mouthparts for obtaining nectar. The blister beetles at times appear suddenly, and Epicauta vittata may destroy large areas of tomatoes and potatoes in a few days. An extended list of the plants on which these beetles feed is given by Gibson in the fourty-second annual report of the Entomological Society of Ontario. In New England only three species of this family have been observed on flowers, but Epicauta pennsylvanica is very common on the flowers on Solidago. Gnathium and Nemognatha, southern and western genera living wholly on nectar, have the maxillæ prolonged into a slender suctorial tube, resembling a lepidoterid tongue. The length of this suctorial tube has been measured in 14 species of Nemognatha, and showed a gradual increase from $1.5 \mathrm{~mm}$. to $10 \mathrm{~mm}$. in length, presenting a complete series of intermediate gradations. ${ }^{2} \quad N$. vittigera, according to Graenicher, visits the flowers of the Compositæ exclusively, chiefly those of Rudbeckia hirta. This observer states that the behavior of these beetles when at work on flowers presents additional evidence of a high degree of adaptation, the tongue being thrust in and removed from the florets with great

\footnotetext{
1 This view is favored by Cockerell's observations on the bee genus Perdita. He states that the length of the tongue appears to have increased or decreased according as the total size of the bee has increased or decreased, not to meet spccial requirements. "The Bees of the Genus Perdita," Proc. Acad. Nat. Sci. Philadelphia, Vol. 48, p. 40.

${ }^{2}$ Graenicher, S., "On the Habits of Beetles of the Genus Nemognatha," Ent. News, Vol. 21, pp. $72-75$.
} 
precision and little loss of time. This is easily the most remarkable modification that anthophily has induced among the Coleoptera; and the origin of a tongue, adapted for sucking nectar, varying greatly in length in the different species, in these two genera, presents a problem difficult of explanation.

There remain for consideration several small families, as the Edemeridæ, Mordellidæ and Anthicidæ, which to a great extent in the adult stage live on flower food; but they do not in any other sense represent the culmination of anthophily among the Coleoptera. The prevalence of anthophily in these families is to be attributed to the comparatively few species, their small size, and the ease with which they can obtain food and shelter in densely clustered small flowers. They exhibit very obscure if any modification of the mouthparts for procuring nectar. The wedge-shaped Mordellidæ are very common, and Frost found the compound cymes of Viburnum loaded with species of Mordella and Anaspis; they may also be found on the inflorescence of Cornus, Prunus, and Spiræa and on the pollen flowers of the wild rose. The New England list contains 12 species, while Knuth records 12 species for Europe and 15 for North America. Only one species of the GEdemeridæ (Asclera ruficollis) has been observed on flowers in New England.

\section{Flowers Visited by the Anthophilous Coleoptera.}

While many of the more important flowers visited by the anthophilous Coleoptera have been mentioned in the preceding pages a brief recapitulation of their mutual relations in New England is desirable. The largest number of species of beetles have been collected on the following genera and species of plants: Viburnum, 81; Cornus, 38; Spiroea salicifolia, 42; Amelanchier canadensis, 31; Prunus virginiana, 43; Pyrus arbutifolia, 10; Ceanothus americanus, 13; Aralia hispida, 9; and Solidago, 30 species. All these flowers have the nectar fully exposed, or only slightly concealed, as in Solidago which has a floral tube $1 \mathrm{~mm}$. long, or a little longer in $S$. lanceolata, and are of small size, densely clustered and very common. The phenomenal number of beetles taken on Viburnum may be partially explained by the great abundance of the flowers, the form of the cymes and the time of anthesis. In a warmer climate the anthophilous Coleoptera would doubtless show a large increase, 
for, in Virginia, Banks collected 58 species on the flowers of Ceanothus, and Hopping reports 56 species taken on the same genus in California. In Virginia, Chauliognathus was most common, while hosts of small Mordellids, and Centrinus picumnus, Macratria murina, Lappus sturmii, Mycterus scaber, Isomira sericea, were always abundant. Eighteen species of Cerambycidæ were obtained, and eleven species were taken at one patch of flowers in less than an hour. In the flowers enumerated nectar is a more important allurement than pollen, which is not produced in large quantities.

In Wisconsin, Graenicher collected 35 species of Coleoptera on the capitula of the Compositæ, but the only genus on which they were common was Solidago. ${ }^{1}$ In New England 30 species have been taken on Solidago, 7 on Eupatorium perfoliatum, 4 on Aster, 6 on Chrysanthemum Leucanthemum, 1 on Taraxicum officinale, 6 on Achillea Millefolium, and 1 on Diplopappus umbellatus. Where the nectar is deeply concealed the beetles usually feed on pollen, e. g., two species taken by Graenicher on the heads of Cirsium lanceolatum, which has a floral tube $6 \mathrm{~mm}$. long were both eating pollen. In the New England list some thirty other flowers are enumerated which are visited by beetles in small numbers. The nectariferous species, as Salix, Daucus Carota, Zizia aureum, Brassica, Rhus, Veratrum, Ranunculus, etc., for the most part have the nectar easily accessible.

Beetles also frequently visit flowers which are devoid of nectar, to obtain pollen. Many anemophilous flowers are sought by beetles in search of pollen, as the staminate cones of Pinus sylvestris and Picea Abies ; numerous beetles, which devour the anthers as well as the pollen, may be swept from the grasses; while others have been collected on the inflorescence of the Cyperaceæ and Juncaceæ. Cistela sericea was found by Frost on the aments of Castanea, upon which two beetles were also taken by Knuth. Flowers intermediate between anemophily and entomophily, as Vitis and Plantago, are freely visited by Coleoptera. Beetles are likewise common on conspicuous pollen flowers, as Rosa, Anemone, Clematis, Adonis, Papaver, Hypericum and Sambucus; and not always content with the pollen they may destroy the entire corolla,

\footnotetext{
${ }^{4}$ Graenicher, S., "Wisconsin Flowers and Their Pollination," Bull. Wisconsin Nat. Hist.
} Soc., Vol. 7, pp. 19-77. 
e. g., Nodonota puncticollis is very destructive to the petals of the rose.

The frequency with which anthophilous Coleoptera visit pollen flowers led Knuth to infer that they exhibit a marked preference for pollen. ${ }^{1}$ That carnivorous forms, like the Coccinellidæ which live largely on Aphides and insect eggs, find pollen a more agreeable food than nectar is not improbable; but if this were generally true of all anthophilous genera then Nemognatha and Gnathium would not have become adapted to feeding on nectar alone. My observations lead me to believe that Chauliognathus, Leptura, Typocerus, Strangalia, the Mordellids and many others manifest a preference for nectar. But genera, as among the leaf-chafers, which occur in enormous numbers must as a necessity feed upon pollen as well as nectar and also on the succulent parts of the plant.

Coleoptera are occasionally taken on zygomorphic or bilabiate flowers with the nectar deeply concealed, where they are either searching for food or their presence is accidental. According to Kerner beetles of the genera Anthobium, Dasytes, and Meligethes find refuge and shelter in the interior of the gentians, while species of Cetonia remain for several days in the partially expanded flowers of Magnolia feeding on the sweet juices and pollen. ${ }^{2}$ Carrion beetles are found in the spathes of the aroids. The interior of flowers is also used for nocturnal lodging, the temperature prevailing within being several degrees warmer than that of the outer atmosphere.

Color and odor are of little significance as allurements to the anthophilous Coleoptera, for although beetles are most frequently found on yellow and white flowers this is not an evidence of "a color preference," as Müller supposed, but is a result incidental to the flower characters previously described. Since, however, beetles are strongly attracted by a bright light it is not unlikely that a sharp contrast in luminosity between the inflorescence and the foliage is noticed by them. It has been frequently asserted that floral odors are very attractive to beetles, but we have met little evidence to support this view, although carrion beetles detect indoloid scents. The writer has exposed free honey for long intervals which attracted Hymenoptera, Diptera and Lepidoptera, but never any Coleoptera. But environment may be an important

1 Knuth, Paul, “Handbuch der Blütenbiologie," Vol. 1, p. 223.

2 Kerner, A., "The Natural History of Plants," Vol. 2, p. 163. 
factor in determining the presence of certain genera. Banks observed that "at a patch near woodlands where there were many dead trees, a considerable variety of Longicorns were always obtainable; at another patch in an open meadow few Longicorns were ever found." 1 The writer has also noticed that while the Cerambycidæ were common on the flowers of Aralia hispida and Spiræa salicifolia in the open woodlands, they were entirely absent in the pastures. Many genera and species of this family follow in their distribution the coniferous forests of the north. ${ }^{2}$ The season of the year is likewise important as fewer beetles are on the wing in September and October than in June and July. ${ }^{3}$ Finally, if the larvæ live on the vegetative organs of a plant the adult beetles may be expected to visit the flowers.

Very few species of the Coleoptera have been recorded as anthophilous compared with the total number described. In all of the families, in most of the genera and in very many species in which anthophily occurs this habit has been acquired independently; but in the case of Gnathium and Nemognatha it probably arose before these genera were differentiated. Except in these two genera and to a less extent in Chauliognathus and the Lepturini the modifications induced are obscure and indistinct, from which it may be inferred that anthophily among the Coleoptera is of comparatively recent origin. The primitive Coleoptera lived largely upon the ground and were carnivorous, but as they learned to search for their prey on plants and to feed on vegetation anthophily became correspondingly more common. As pollinators of flowers the anthophilous beetles are of little significance. The enormous devastation of the vegetative organs of plants by beetles both in the larval and adult stages, the consumption and waste of the pollen and nectar, the destruction of the petals and other floral members, the absence of hair for holding pollen, the inactivity of many species and their indefinite manner of flight are factors which greatly reduce their value as pollen carriers. Floral structure shows absolutely no response to the visits of beetles, and there is

\footnotetext{
${ }^{1}$ Banks, N., "At the Ceanothus in Virginia," Ent. News, Vol. 23, p. 102. Cf. also Hopping, R., "Some Notes on Coleoptera Found on Species of Ceanothus," Ent. News, Vol. 10, pp. 162165 .

2 Wickham, H. F., "A List of the Coleoptera from the Southern Shore of Lake Superior," Proc. Davenport Acad. Nat. Sci., Iowa, Vol. 6, p. 127.

3 Loew, E., "Der Blumenbesuch der Insekten im Wechsel der Jahrzeit," Bot. Vereins der Provinz Brandenburg, Vol. 47, p. 25.
} 
no reason to suppose that the development of the entomophilous flora would have varied in any respect had entomophily never arisen among the Coleoptera.

\title{
TABLE OF NORTH AMERICAN SPECIES OF THE DIP- TEROUS GENUS THRYPTICUS, WITH DESCRIP- TIONS OF FOUR NEW SPECIES.
}

\author{
By Millard C. Van Duzee, \\ Buffalo, New York.
}

While studying the Thrypticus in my collection and a little material that came to hand $I$ found four forms that seem to be new. These are described below.

In willistoni Wh. the fore and middle coxæ may be mostly yellow or infuscated almost to the tips, while in the female they may be somewhat blackened. This seems to be our most abundant species in wéstern New York. I have seen examples from New England; Toronto, Ont.; and Columbia, Mo. I have taken a number of $\boldsymbol{T}$. fraterculus Wh. at Lewiston, N. Y., and have seen a series of eight from Berkeley Hills, Cal.; Professor Aldrich reports it from Mexico.

The species of Thrypticus are minute flies of bright metallic color with a concave area in front of the scutellum and with the bristles and hairs of the thorax and abdomen yellow; the third and fourth longitudinal veins are usually convergent at tip, but sometimes parallel, and the hypopygium is flexed under the abdomen, often reaching nearly to the thorax.

The hypopygia of the males of those species I have examined are very similar. There is a large capsule or outer part which is covered with scales of pollen that are always inclined backward. Its appendages are lamelliform with a pair of slender processes at their base in most species (these seem to be lacking in willistoni). There is also a central filament (the penis) which originates on or near the base of the hypopygium and usually extends nearly to the end of the lamellæ; this filament is inclosed in a sheath which is shorter and often so closely applied to it that the two appear to form one piece. In the drawing of aurinotatus sp. nov. this filament does not show as it was folded under the abdomen. 

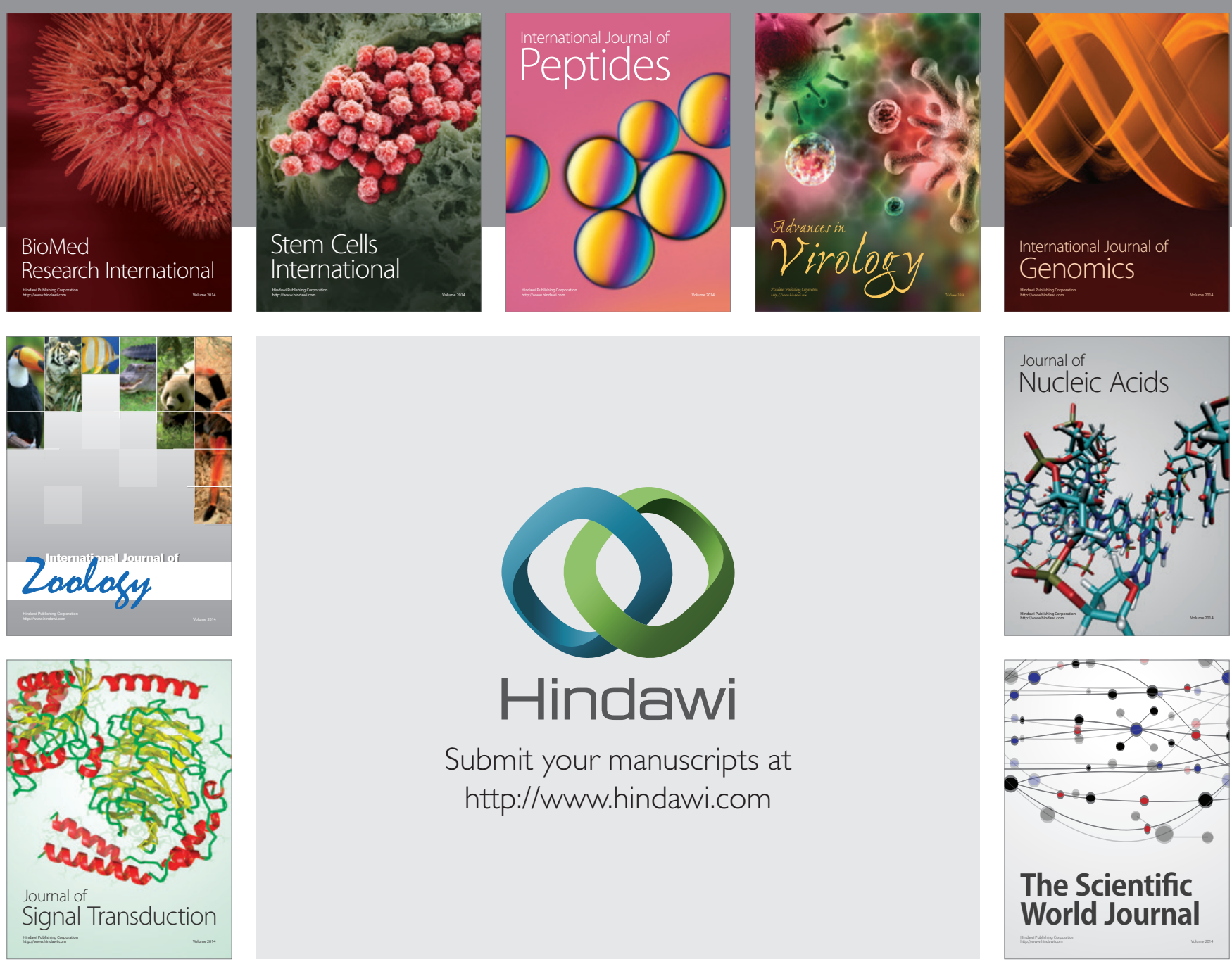

Submit your manuscripts at

http://www.hindawi.com
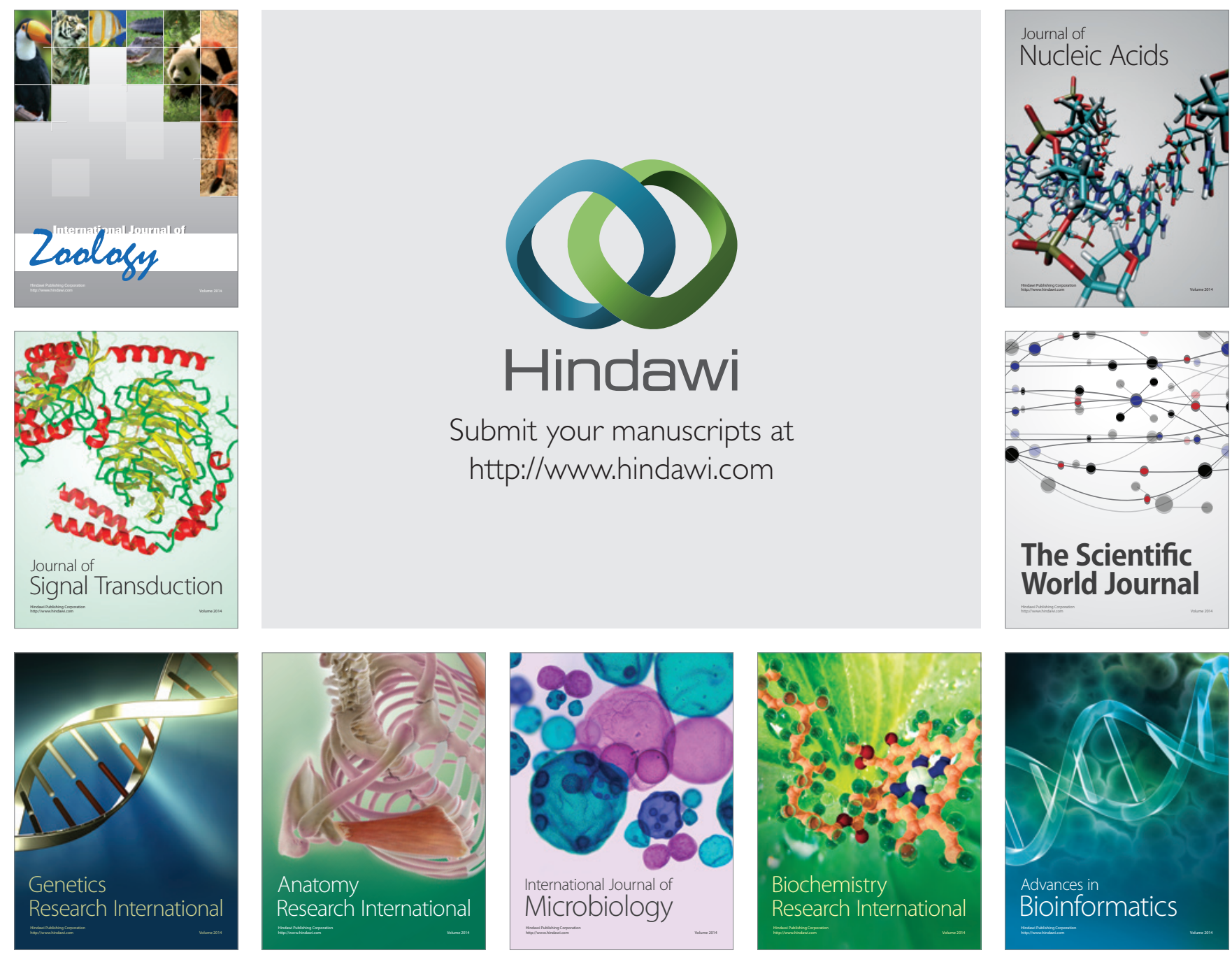

The Scientific World Journal
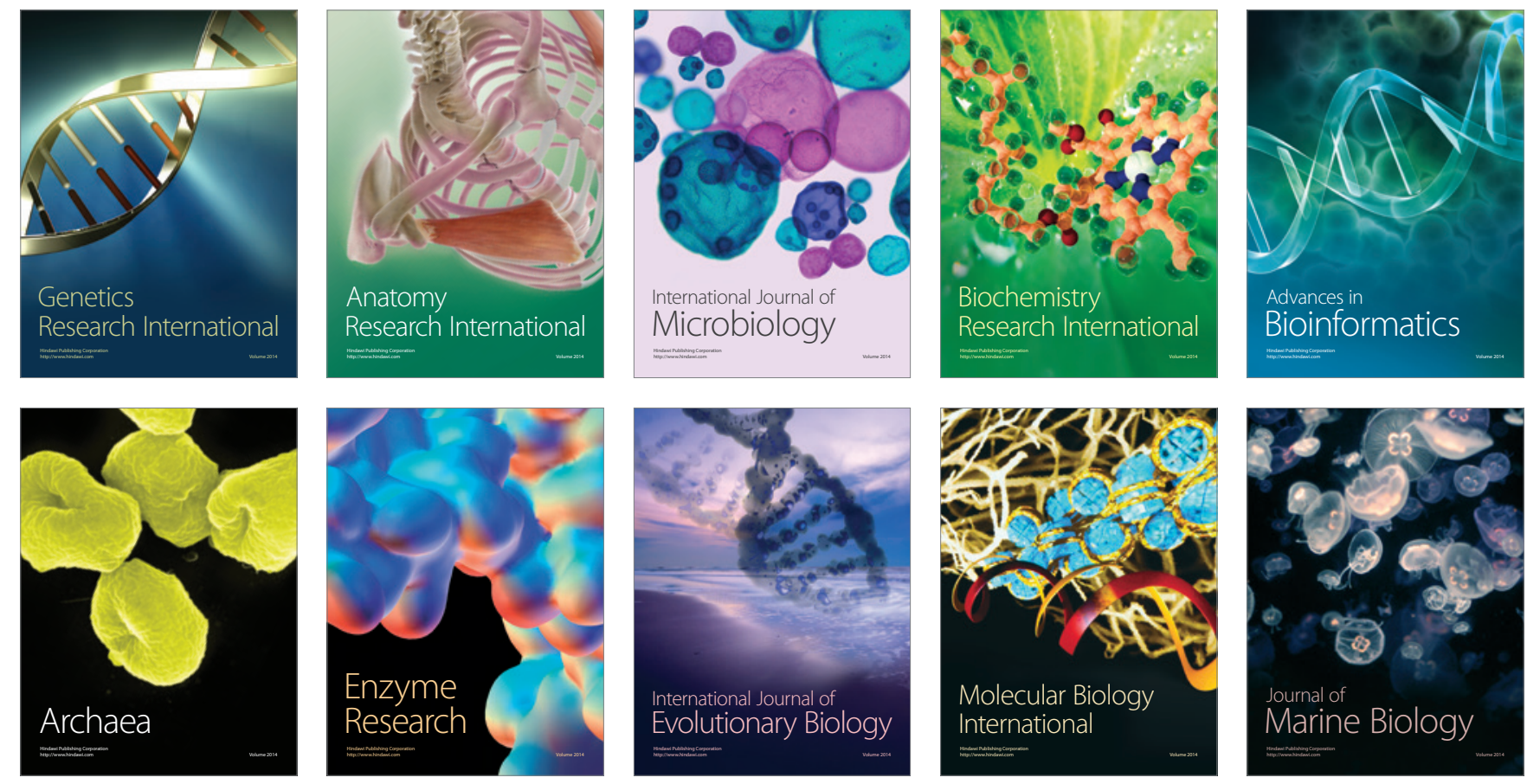